\title{
THE EFFECT OF FOREIGN DIRECT INVESTMENT SPILLOVER ON THE LEVEL OF TECHNICAL EFFICIENCY IN LARGE AND MEDIUM MANUFACTURING INDUSTRY IN EAST JAVA
}

\author{
Ahmad Oktabri Widyananda ${ }^{1}$ \\ Dyah Wulan Sari ${ }^{2 *}$ (D) \\ 1,2 Department of Economics, Universitas Airlangga, Indonesia
}

\begin{abstract}
Foreign Direct Investment (FDI) takes an important role in the development process, especially in developing countries. The purpose of this study is to examine and analyze FDI spillover on the level of technical efficiency in the large and medium manufacturing industry in East Java. This study uses a time-varying stochastic frontier approach for firm-level panel data of the East Java manufacturing industry. The results show that all factors in this study affect the level of technical efficiency of large and medium industries in East Java. Variable foreign share, FDI horizontal spillover, and firm size have a positive influence on the technical efficiency of the industry. Whereas the variable FDI backward spillover, FDI forward spillover and the level of market concentration negatively affect the level of technical efficiency of the industry. Finally, it's needed to build synergies and sustainable relationships between products produced by domestic and foreign firms. Thus, the presence of foreign firms in East Java could have a positive impact on improving the technical efficiency of the domestic industry both at the upstream and downstream levels.
\end{abstract}

Keywords: Foreign Direct Investment Spillover, Technical Efficiency, East Java Industry

JEL Classification: F21, L60, D24

\section{ARTICLE INFO}

Received: October $17^{\text {th }}, 2019$

Revised: April 30 ${ }^{\text {th }}, 2020$

Accepted: May 6 $6^{\text {th }}, 2020$

Online: June $10^{\text {th }}, 2020$

${ }^{*}$ Correspondence: Dyah Wulan Sari E-mail:

dyah-wulansari@feb.unair.ac.id

To cite this document: Widyananda, A.O., \& Sari, D.W., (2020). The Effect of Foreign Direct Investment Spillover on The Level of Technical Efficiency in Large and Medium Manufacturing Industry in East Java. JDE (Journal of Developing Economies), Vol. 5 (1), 5-19.

\section{Introduction}

Developing countries could be attractive destinations for international investors. Foreign Direct Investment (FDI) also takes an important role in the development process, especially in developing countries. Some important roles of FDI include: First, FDI provides an important source of funds for industrial development (Ni, 2011; Yin, 2010). Second, FDI can increase industrial productivity in the host country through advanced production and management systems (Cheng, 2012; Jin and Tokunaga, 2007; Saggi, 2002; Ni, 2011; Yin, 2010). Third, the domestic industry may benefit from global market information and technology spillovers, and become more competitive in international markets (Lv and Huang, 2006).

Apart from the potential benefits of having FDI above, there are also concerns that FDI will be able to cause negative spillovers in the development of domestic companies (Aitken and Harrison, 1999; Djankov and Hoekman, 2000; Görg and Greenaway, 2004; Konings. 2001).

JDE (Journal of Developing Economies) p-ISSN: 2541-1012; e-ISSN: 2528-2018

DOI: http://dx.doi.org/10.20473/jde.v5i1.15646

Open access under a Creative Commons Attribution 4.0 International

(CC-BY) 
Other studies have shown that FDI can cause crowding out of domestic companies (De Backer and Sleuwaegen, 2003; Kosová, 2010).

The role of FDI in Indonesia is greater than domestic investment. Total domestic and foreign investment in Indonesia in 2018 reached 721.3 trillion rupiahs. This figure is the accumulation of domestic investment which reached 328.6 trillion rupiahs and FDI which reached 392.7 trillion rupiahs (BKPM RI, 2019). East Java Province takes a quite large role with investment realization worth USD 1.33 billion. The total investment value is a combination of 1,441 projects implemented in East Java during 2018.

In terms of utilization, FDI in East Java is widely used for industrial purposes. This is evidenced by the data in 2018 which shows the dominance of the industrial business sector as the most sector financed by foreign investors in East Java. We can see the dominance of 7 industrial sectors from a total of 11 business sectors funded by foreign investors in East Java. The seven industrial business sectors can attract investment of 13.27 trillion rupiahs $(74.26 \%)$. While the other business sectors can attract investment of 4.6 trillion rupiahs $(25.74 \%)$.

Based on the descriptions above, we can understand that the important role of industry is also much in demand by foreign investors to invest in East Java. This requires the industry to be more advanced and efficient. Many researchers previously tried to find out how efficient the manufacturing industry was to provide a comprehensive analysis for decision-makers both by shareholders, managers, and investors (Soetanto, 2015). They examined the efficiency of various types such as the garment industry, manufacturing, agriculture, and retail.

In 2014, large and medium industries in East Java had various levels of technical efficiency. Technical efficiency is related to the company's ability to produce at a certain level of output using minimum inputs at a certain technological level. The five types of industries that have the lowest level of technical efficiency are shown in the table below.

Table 1: The Lowest Industrial Technical Efficiency Level in East Java, 2014

\begin{tabular}{cclc}
\hline No. & ISIC Code & \multicolumn{1}{c}{ Type of Industry } & $\begin{array}{c}\text { Technical } \\
\text { Efficiency }\end{array}$ \\
\hline 1 & 10214 & Fish Scavenging Industry & 0,747 \\
\hline 2 & 10291 & Salting / Drying Industry of Other Water Biota & 0,764 \\
\hline 3 & 10221 & $\begin{array}{l}\text { Processing and Preservation Industry of Fish and } \\
\text { Aquatic Biota (Non-Shrimp) in Cans }\end{array}$ & 0,775 \\
\hline 4 & 10297 & Other Biota Water Cooling Industry & 0,777 \\
\hline 5 & 10299 & $\begin{array}{l}\text { Other Processing and Preservation Industry for Oth- } \\
\text { er Water Biota }\end{array}$ & 0,785 \\
\hline
\end{tabular}

Source: BPS (2019)

The five industries that have the lowest level of technical efficiency come from industries related to processing marine products such as fish and other types of aquatic biota. The five types of industries are classified as industries that are less attractive to foreign investors. Based on these data, there are indications that the absence of FDI in an industry tends to lower the technical efficiency of the industry, of course by not ignoring other factors that can also affect the technical efficiency of the industry.

Based on some backgrounds such as the development of FDI at the world level, Indonesia, and in East Java; the performance and important role of the industrial sector in East Java; as well as an overview of the technical efficiency of the industry in East Java, the analy- 
sis of the Effect of Spillover FDI on the Level of Technical Efficiency in the Large and Medium Processing Industries in East Java is interesting to do.

\section{Literature Review}

There are some points will be discussed in the literature review: production theory, the concept of technical efficiency, and foreign direct investment spillovers.

\section{Production Theory}

In the conventional production function, we know that the basic activity of any company is to change inputs into outputs. Economists are challenged to find out the choices made by the company in achieving this goal, but they want to avoid complicated discussions about the techniques used, therefore economists agree to build an abstract production model (Nicholson and Snyder, 2012). In this abstract model, the relationship between input and output can be formulated as follows:

$$
Q=f(K, L, M, E)
$$

Where:

$f \quad=$ The production function is to produce output in the form of $q$ from several inputs such as $\mathrm{k}, \mathrm{l}, \mathrm{m}$

$Q \quad=$ Firm output for certain goods in a certain period

$K=$ Capital (for example machines) used in a certain period

$L=$ Labor

$M \quad=\quad$ Used material

$E \quad=$ The possibility of adding other variables that affect the production process

There are some production functions in economics that developed year to year. Starting from the problem that there are no variables taken from measurement errors and statistical noise (in the Data Envelopment Analysis method), where all deviations from the frontier are assumed to be technical inefficiencies, then Aigner et al. (1977), and Meeusen and van den Broeck (1977) introduced the stochastic frontier production function in the form of:

$$
q i=x^{\prime} i \beta+v i-u i
$$

This production function contains a statistical random error element to indicate statistical noise. Statistical noise arises because of the accidental deletion of related variables from vector $x_{i^{\prime}}$ as well as from error measurement and estimation related to the choice of functional form. That model is called the stochastic frontier production function because its output value is limited by stochastic variables. Variable $v_{i}$ can be both positive and negative, so the stochastic frontier output value can vary according to the deterministic part of the model (Battese and Coelli, 1992; Khumbhakar, 1990).

In economics and econometrics, the Cobb-Douglas production function is a specific functional form of the production function which is widely used to describe the technological relationship between two or more inputs (usually capital and labor) with the amount of output that these inputs can produce. The Cobb-Douglas production function was developed and tested against statistical evidence by Charles Cobb and Paul Douglas from 1927-1947 (Cobb and Douglas, 1928). The Cobb-Douglas production function can also be used in many applications because of its linear nature in the form of logarithms (Nicholson and Snyder, 2012). This can be written in the following equation : 


$$
\ln q=\ln A+\alpha \ln k+\beta \ln l
$$

The constant $\alpha$ is the output elasticity associated with capital input, while $\beta$ is the output elasticity related to labor input. Both constants can be estimated from actual data, and the estimation can be used to measure the level of returns to scale (by adding $\alpha+\beta$ ) and other purposes.

The next production function is Translog. The translog production function provides several advantages (Paveslescu, 2011): 1) Unlike the Cobb-Douglas function, the translog function does not use assumptions such as perfect substitution between factors of production or perfect competition in the factor market (J. Klacek et al., 2007); 2) The concept of the translog production function permits a linear relationship between output and factors of production which are taken into account moving to a non-linear relationship; 3) The translog production function can be used for the second-order approach of homogeneous linear production, estimation of Allen elasticity substitution, estimation of production frontier or measurement of the dynamics of the total factor productivity. If we use four factors, the translog production function can be written as follows :

$$
\begin{aligned}
\ln Y= & \ln A+\alpha_{K} \ln K+\alpha_{L} \ln L+\alpha_{M} \ln M+\alpha_{E} \ln E+b_{K K} \ln ^{2} K+b_{L L} \ln ^{2} L \\
& +b_{M M} \ln ^{2} M+b_{E E} \ln ^{2} E+b_{K L} \ln K \ln L+b_{K M} \ln K \ln M+b_{K E} \ln K \ln E \\
& +b_{L M} \ln L \ln M+b_{L E} \ln L \ln E+b_{M E} \ln M \ln E
\end{aligned}
$$

Where:

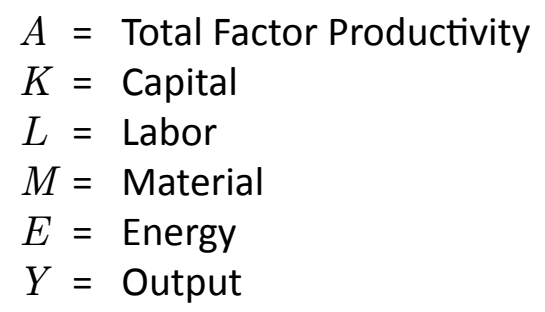

The translog production function is used as a reference model and will be tested with various production functions such as : Hicks-neutral technological progress, no technology progress, Cobb-Douglas and no inefficiency effect. The Hicks-neutral technological progress production function is used when there is an interaction of input coefficients with time equal to $0(\beta \mathrm{kt}=0)$. The production function of no technology progress is used when the time coefficient is equivalent to $0(\beta \mathrm{t}=\beta \mathrm{tt}=\beta \mathrm{kt}=0)$. The Cobb-Douglas Production Function is used when the input coefficient is equal to $0(\beta \mathrm{kl}=\beta \mathrm{kt}=\beta \mathrm{t}=\beta \mathrm{tt}=0)$. Whereas the production function of no inefficiency effect is used when the coefficient of the inefficiency function is equal to $0(\gamma=\delta 0=\delta m=0)$, where $\gamma$ is a variant of the inefficiency function. If $\gamma=0$, then the conventional production function with the exogenous variables involved in the model will be eliminated.

\section{The Concept of Technical Efficiency}

Technical efficiency is the ability of a company to obtain maximum output from the use of a set (bundle) of inputs. Technical efficiency is related to a company's ability to produce on an isoquant frontier curve. Another definition shows that technical efficiency is the ability of a company to produce at a certain level of output by using minimum inputs at a certain technological level (Coelli et al, 2005). The technical efficiency of production by firm i in year t can be written as follows: 


$$
\begin{aligned}
T E_{i t} & =\frac{y_{i t}}{\hat{y}_{i t}} \\
& =\frac{f\left(x_{i t}, z_{i t} ; \beta, \tau\right) \cdot \exp \left(v_{i t}-u_{i t}\right)}{f\left(x_{i t}, z_{i t} ; \beta, \tau\right) \cdot \exp \left(v_{i t}\right)} \\
& =\exp \left(-u_{i t}\right) \\
& =\exp \left(-z_{i t} \delta-\omega_{i t}\right)
\end{aligned}
$$

The equation above shows that technical efficiency is measured based on the ratio between realized output ( $y_{i t}$ ) and the maximum potential output that is possible to be produced $\left(\hat{y}_{i t}\right)$. Therefore, the value of technical efficiency will vary between 0 and 1 . The most efficient company or can be said the best-practice firm has a value of technical efficiency equal to 1 , while less efficient companies have a value of technical efficiency below 1 .

\section{Foreign Direct Investment Spillovers}

According to the OECD (2009), to determine a company said to be a foreign company can use a threshold value of the percentage of ownership on foreign assets. All companies which have a percentage of foreign assets of at least $10 \%$ will be considered as foreign companies. However, in this study, the foreign ownership variable is not measured using a threshold value but is measured using a dummy variable and can be denoted as follows:

$$
\begin{aligned}
F O R_{i t} & =1 \text { if firm i at time t has a share of foreign ownership of any percentage } \\
& =0 \text { if others }
\end{aligned}
$$

Many theoretical arguments indicate that the externality of FDI can not only increase the productivity of domestic firms through technology but also can increase firm efficiency. The presence of FDI can help domestic firms to apply the latest technology to make sophisticated products more efficient. Not only that, but the presence of FDI can also stimulate domestic firms to learn about the management of foreign firms to achieve optimal production scale. Increased productivity gained from the presence of foreign firms in line with the benefits of technology. Firms in developing countries are often less innovative when compared to foreign firms from developed countries, therefore the presence of foreign firms can also inspire local firms to develop their research and development (R\&D) activities (Cheung et al, 2004). This will help domestic firms to innovate.

Increased productivity gained from the presence of FDI can be channeled in two ways: the intra-industrial productivity spillover and the inter-industrial productivity spillover (Javorcik, 2004; Girma et al, 2009; Lin et al, 2009; Keller, 2009; Bwalya, 2006). If the presence of foreign firms can encourage the productivity of domestic firms in the industrial sector, then the spillover is considered as horizontal spillovers. Besides that, if their presence can increase the productivity of domestic firms outside the industrial sector, then the spillover is called inter-industrial spillover.

The equation of horizontal spillover can be written as follows:

$$
H \operatorname{Spill}_{j t}=\frac{\sum_{i \in j} F S h_{i t} * Y_{i t}}{\sum_{i \in j} Y_{i t}}
$$

HSpill $=$ Horizontal overflow effect

$F S h=$ Total share from foreign investors

$Y \quad=$ Output 


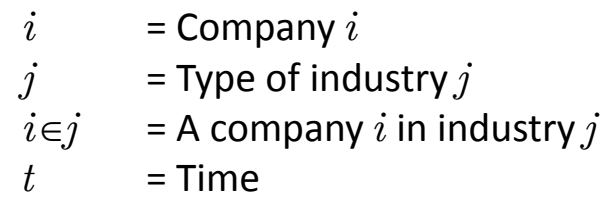

In addition to horizontal spillover, the impact of FDI entry is the presence of vertical (inter-industry) spillover. This type of impact will arise when foreign firms have links with upstream and downstream industries in the host country (Rodriguez-Clare 1996; Javorcik 2004; Blalock and Gertler 2008; Sharma et al, 1998). Domestic firms in the local market that have foreign firms as buyers of intermediate inputs that are produced, will have a backward spillover effect. Meanwhile, domestic firms in the local market that have foreign firms as their suppliers of intermediate inputs, will have a forward spillover effect. The equation of both spillovers can be written as follows:

$$
\operatorname{BSpill}_{j t}=\sum_{k} b_{k l} * H \operatorname{Spill}_{j t}
$$

$b_{k l} \quad=$ The amount of industrial output $k$ demanded by an additional unit of industrial output $l$ produced

$b_{k l}{ }^{*} H_{S p i l l}=$ Intermediate product each element of Bkl and the degree of connectedness of the presence of foreign investment (to measure the derivative demand from the presence of foreign investment for industrial output $k$ )

$$
F_{S p i l l}^{j t}=\sum_{l} b_{k l} * \frac{\sum_{i \in j} F S h_{i t} *\left(Y_{i t}-X_{i t}\right)}{\sum_{i \in j}\left(Y_{i t}-X_{i t}\right)}
$$

$b_{k l} \quad=$ The number of demand for industrial output $k$ used as input to produce a unit of industrial output $l$

The Input-Output table in this study is used to measure the forward and backward spillover effects of foreign direct investment, especially the Leontief inverse matrix that displays both direct and indirect linkage effects (inter-sectoral linkages). The measurement of vertical linkage in this study refers to research conducted by Kohpaiboon (2009). The research is different from Javorcik (2004) and Blalock and Gertler (2008) where the vertical linkage proxy only shows direct linkages.

Inter-industry linkage is calculated based on the Leontief inter-industry accounting framework as follows:

$$
\begin{aligned}
X & =A^{d} X+Y^{d}+E, A^{d} \\
& =\left[a_{k l}\right], a_{k l} \\
& =\frac{X_{k l}}{X_{l}}
\end{aligned}
$$

The solution for $\mathrm{X}$ :

$$
\begin{aligned}
X & =\left[I-A^{d}\right]^{-1}\left[Y^{d}+E\right],\left[I-A^{d}\right]^{-1} \\
& =\left[b_{k l}\right]
\end{aligned}
$$

$X=$ Column vector of total gross output

$A^{d}=$ Domestic input-output coefficient matrix 
$\left[a_{k l}\right]=$ Domestic input-output coefficient element matrix

$Y^{d}=$ Column vector of domestic demand on domestic product

$E \quad=$ Export demand column on domestic product

$\left[b_{k l}\right]=$ Domestic Leontief inverse matrix

The domestic Leontief inverse matrix $\left(b_{k l}\right)$ will show direct or indirect (inter-sectoral) links in the measurement process. The matrix will show the total units of output needed, both directly and indirectly, from all sectors when the demand for industrial products increases by one unit.

In addition to FDI spillovers, the authors add two other factors to examine their effects on technical efficiency. These factors are the level of market concentration and firm size. The level of market competition can affect the efforts of managers and workers in developing their firms. Managers and workers in firms on the monopoly market will have a lower level of hard work than firms in a perfectly competitive market. Therefore, the competition will make firms to be more efficient (Sari et al., 2016). The competition will also increase productivity and the emergence of new innovations.

Measurement of the level of market competition can use HHI. The measurement of the market competition level of industry $j$ at time $t$ can be written as follows:

$$
H H I_{j t}=\sum_{i=1}^{n} s_{i t}^{2}
$$

$H H I_{j t}=$ The market concentration of industry $j$ at time $t$

$s_{i t}^{2} \quad=$ Market contribution from each firm

Studies on firm size have been carried out by many experts, one of them Coase (1937), which raises the question of how firm size can affect resource allocation within the firm. Firm size variables will also be included in the model in this study. Based on several studies such as Moulton (1990) and Kohpaiboon (2009), firm size in the model influences industry effects, especially when using industrial samples and using aggregation. In this study, firm size is measured using the output of firm i divided by the output of industry $j$ at time $t$.

\section{Data and Research Methods}

Following the formulation of the problem in the introduction, this study uses a quantitative approach using statistical procedures or other ways of quantification (measurement). According to Neuman (2003), there are 3 (three) types of research commonly used in quantitative research, namely: experiments, surveys, and content analysis. In this research, the type of research used is experiment. According to Sujarweni (2015), "the experimental method is a method that has the aim to explain the causal relationship (causality) between one variable with another (variable $\mathrm{X}$ and variable $\mathrm{Y}$ )".

The main variables used in the frontier production model consist of output and input variables. The output variable is a proxy of overall total output. This variable refers to the total value of output produced by the firm in a particular year. Input variables in the form of capital are measured by calculating the value of fixed assets, such as: land and buildings, company machines, and assets in the form of vehicles. While the input variable in the form of labor is measured by calculating the amount of labor used. The input variable in the form of material is the total cost of local and imported raw materials used during the production process. Meanwhile, input variables in the form of energy are measured based on the amount of com- 
pany spending on the use of fuel oil, gas and electricity.

Material input and output, energy, and capital stock expressed in terms of currency in units of thousands of rupiah. Therefore it is necessary to convert the value of the currency to its true value. The total value of inputs and outputs is converted using the Wholesale Price Index (WPI) published by BPS using a constant price in 2005. While the value of imported materials is also adjusted by referring to the currency exchange index. In addition to the input and output variables, there are other variables that are also counted in this study, such as foreign share, FDI horizontal spillover, market structure, and firm size. Other variables obtained from the calculation results by combining Large and Medium Industry Data with Input-Output Table data are the variable FDI backward spillover and FDI forward spillover.

The used data in this study are secondary data obtained from the 2008-2014 Large and Medium Industry Survey conducted by the Central Statistics Agency (BPS). This survey was conducted using the census method involving all large and medium industrial companies in Indonesia. From the national scale data, the writer limits the focus of research on large and medium industries in East Java. This study also uses input-output table data with base years 2005 and 2010. This is done because of the vulnerable time of industrial data used is from 2008 to 2010. For industrial data in 2008 and 2009, the writer used the data input-output table for the base year 2005, while for industrial data from 2010 to 2014 the writer used the input-output table data for the base year 2010.

This study uses a time-varying stochastic frontier production function for panel data that focuses on the influence of FDI variables. These variables make it possible to influence the firm's technical efficiency and are closely related to the environment in which the production process is carried out. The theoretical argument states that the benefits derived from the existence of FDI are not only technological benefits but also increase the value of the company's production efficiency. The way to combine these variables into a stochastic frontier approach is to add FDI variables to the production function and the inefficiency function.

Besides, this study also uses a hypothesis test to determine which production function is most appropriate for interpretation. The main production function to be tested is the translog production function, while the other production functions that will also be tested are: Hicks-neutral technological progress, no technology progress, Cobb-Douglas, and no inefficiency effect. The selection of production functions is using the Frontier 4.1 application through the likelihood ratio (LR) approach. The LR test considers the $\lambda$ parameters obtained through calculations:

$$
\lambda=-2\left[\lambda\left(H_{0}\right)-\lambda\left(H_{1}\right)\right]
$$

Where:

$\lambda\left(H_{0}\right)=$ The value of likelihood log function on the null hypothesis

$\lambda\left(H_{1}\right)=$ The value of likelihood log function on the alternative hypothesis

After obtaining the value, the parameter $\lambda$ is compared to $\chi 2$ with the degree of freedom equal to the number of parameters involved in the restriction. If the calculated $\lambda$ likelihood calculation results are greater than $\chi 2$ tables then $H_{0}$ is rejected or in other words accept $H_{1}$.

This research hypothesis is used to determine the effect of FDI spillover variables and other control variables (foreign share, market structure, and firm size) on the level of technical 
efficiency of large and medium manufacturing industries in East Java. Therefore, based on the background, problem formulation, objectives, and theoretical basis explained in the previous chapters, this research has the hypothesis "foreign share, FDI horizontal spillover, FDI backward spillover, FDI forward spillover, market structure, and the firm size affects the level of technical efficiency of large and medium manufacturing industries in East Java."

\section{Finding and Discussion}

After conducting the testing process to select the form of the production function to be used, the results show as follows:

Table 2: Estimation Result of Translog Stochastic Frontier Production Function and Translog's Sub Models

\begin{tabular}{cccc}
\hline Model & $\lambda$ & $\lambda^{2}$ & Conclusen \\
\hline Hicks Neutral & $-15561,61$ & 13,277 & Ho Rejected \\
\hline No Tec Progress & $-15561,61$ & 16,812 & Ho Rejected \\
\hline Cobb-Douglas & $-15561,61$ & 23,209 & Ho Rejected \\
\hline No inefficiency & 1322,7823 & 20,972 & Ho Rejected \\
\hline Source: The Result of Processing Data by Frontier 4.1 Application &
\end{tabular}

After comparing the parameters $\lambda$ with $\chi 2$ at the same degree of freedom as the number of parameters involved in the restriction, the $\lambda$ likelihood calculation results are smaller than $\chi 2$ tables. Therefore the four translog sub-models are not used or in other words, $\mathrm{HO}$ is rejected. This confirms that the translog function is an appropriate function used in this study.

Large and medium industries in East Java (2008 to 2014) have varying levels of technical efficiency. Its development has also fluctuated from year to year shown in the graph below.

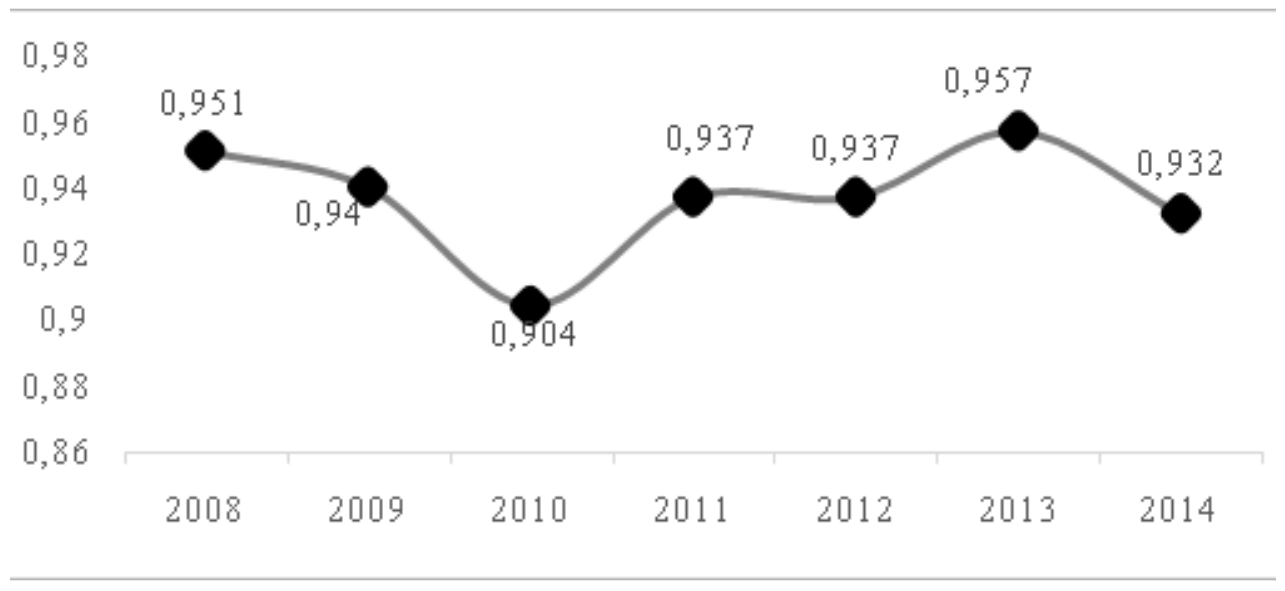

Source: BPS, 2019

Figure 1: Development of Average Value of Industrial Technical Efficiency Year 2008-2014

If we observe the picture above, the average value of the best level of industrial technical efficiency was achieved in 2013 which reached 0.957, while the lowest value occurred in 2010 which only reached 0.904 . This indicates that industrial firms in 2013 were able to manage their resources more efficiently than in 2010. Industrial firms in 2013 were more able to optimize inputs to be output so that not too many resources were wasted. 


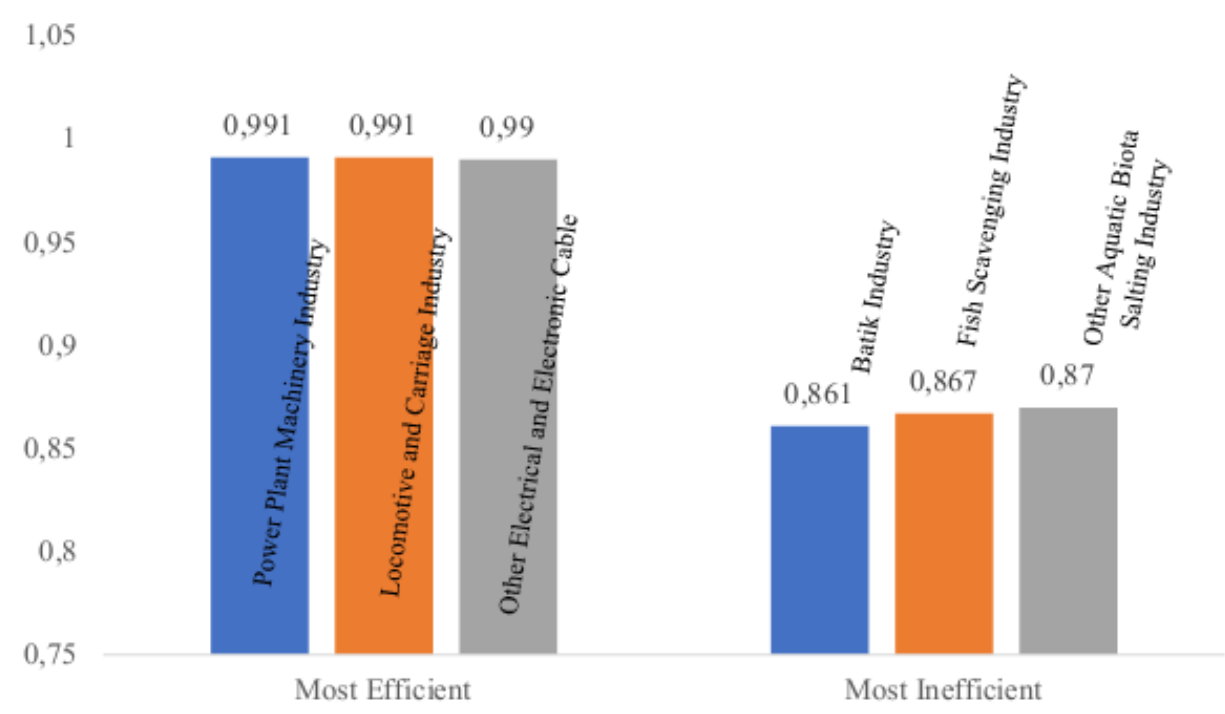

Source: BPS, 2019

Figure 2: The Most Efficient and Most Inefficient Industrial TypesYear 2008-2014

The three types of industries that had the highest average value of technical efficiency during 2008-2014 were occupied by the Power Plant Machinery Industry, the Locomotive and Carriage Industry, and the Other Electrical and Electronic Cable Industry. These three types of industries outperformed other types of industries because they managed their resources in the most efficiently. In contrast, the Batik Industry, Fish Scavenging Industry, and Other Aquatic Biota Salting Industry are the three types of industries with the lowest average technical efficiency. This indicates that the three types of industries are less efficient in managing their resources compared to other types of industries.

In carrying out hypothesis verification, each independent variable is tested by comparing the value of the the $t$ ratio with $t$ table. The critical values used to test the $t$ ratio are 2.34 at a significance level of 1\%; 1.62 at the significance level of 5\%; and 1.28 at a significance level of $10 \%$. The testing results of the simultaneously estimated inefficiencies model are displayed in the table below.

Table 3: Results of Estimation Models of Inefficiency Effects on the Translog Production Function

\begin{tabular}{cccc}
\hline Variable & Coefficient & Standard Error & t-ratio \\
\hline Constant & 0,102 & 0,004 & 27,055 \\
\hline $\mathrm{K}$ & 0,127 & 0,002 & 79,356 \\
\hline $\mathrm{L}$ & 0,140 & 0,002 & 57,833 \\
\hline $\mathrm{M}$ & 0,573 & 0,002 & 268,481 \\
\hline $\mathrm{E}$ & 0,200 & 0,002 & 103,917 \\
\hline $\mathrm{Kk}$ & $-0,030$ & 0,001 & $-23,057$ \\
\hline $\mathrm{LI}$ & 0,022 & 0,003 & 7,863 \\
\hline Variable & Coefficient & Standard Error & t-ratio \\
\hline $\mathrm{Mm}$ & 0,207 & 0,003 & 71,254 \\
\hline Ee & 0,118 & 0,004 & 30,079 \\
\hline $\mathrm{KI}$ & 0,012 & 0,002 & 7,302 \\
\hline $\mathrm{Km}$ & $-0,012$ & 0,002 & $-7,739$ \\
\hline
\end{tabular}




\begin{tabular}{cccc}
\hline Variable & Coefficient & Standard Error & t-ratio \\
\hline Ke & 0,038 & 0,002 & 22,795 \\
\hline Lm & $-0,052$ & 0,002 & $-23,798$ \\
\hline Le & 0,013 & 0,002 & 5,574 \\
\hline Me & $-0,162$ & 0,003 & $-54,253$ \\
\hline$T$ & $-0,007$ & 0,001 & $-9,022$ \\
\hline Tt & $-0,041$ & 0,001 & $-39,647$ \\
\hline Kt & 0,009 & 0,001 & 13,956 \\
\hline Lt & $-0,007$ & 0,001 & $-7,029$ \\
\hline Mt & $-0,001$ & 0,001 & $-1,403$ \\
\hline Et & $-0,006$ & 0,001 & $-6,428$ \\
\hline Constant & 0,125 & 0,003 & 36,374 \\
\hline Fsize & $-0,523$ & 0,014 & $-36,617$ \\
\hline HHI & 0,275 & 0,014 & 20,076 \\
\hline FOR & $-0,005$ & 0,004 & $-1,392$ \\
\hline Hspill & $-0,389$ & 0,015 & $-26,584$ \\
\hline Bspill & 0,002 & 0,001 & 2,029 \\
\hline Fspill & 0,010 & 0,001 & 9,189 \\
\hline The & &
\end{tabular}

Source: The Result of Processing Data by Frontier 4.1 Application

On the foreign share variable, the value of the $t$ ratio is -1.392 . This value is smaller than $t$ table at the $10 \%$ significance level. This means that the presence of foreign share affects the level of industrial technical efficiency. The existence of a negative coefficient $(-0.005)$ indicates that foreign share will reduce the value of technical inefficiency or in other words a positive effect on the industrial technical efficiency in East Java.

The result above is following the results of research conducted by Khalifah and Talib (2008) and Darmawan (2016) which state that foreign investment in a firm has a positive influence on technical efficiency. Firms that have a percentage of foreign ownership have a higher value of technical efficiency because they have better knowledge and production techniques, more sophisticated technology, and greater assets.

On the FDI horizontal spillover variable, the value of the $t$ ratio is -26.584 . This value is smaller than $t$ table at a $1 \%$ significance level. This means that the presence of FDI horizontal spillover affects the level of industrial technical efficiency. The existence of a negative coefficient $(-0.389)$ indicates the presence of FDI horizontal spillover will reduce the value of technical inefficiency or in other words a positive effect on the industrial technical efficiency in East Java.

That result is in line with research conducted by Nguyen, et al. (2008) and Darmawan (2016). The study concluded that the presence of FDI horizontal spillover would improve industrial technical efficiency. The benefit of the FDI horizontal spillover is the positive externalities in the form of knowledge that can enhance domestic industrial product innovation. Besides, the presence of foreign firms will also increase competition in the domestic and international markets, thus encourage domestic firms to innovate continuously and achieve efficient production levels.

On the FDI backward spillover variable, the value of the $t$ ratio is 2.029 . This value is greater than $t$ table at the $5 \%$ significance level. This means that the presence of FDI backward 
spillover influences the level of industrial technical efficiency. The existence of a positive coefficient (0.002) indicates an FDI backward spillover will increase the value of technical inefficiency or in other words negatively affect the industrial technical efficiency in East Java.

The results above are following what has been studied by Sari, et al. (2016) which states that the negative effect of FDI backward spillover can occur if intermediate goods produced by local industry are not widely used by foreign firms as input for their raw materials. In this study, FDI backward spillover harms the industrial technical efficiency in East Java. This indicates that the greater demand for goods from foreign firms to the domestic upstream industry will reduce the value of the technical efficiency of the domestic industry. In other words, the domestic upstream industry has become increasingly inefficient by the entry of foreign firms.

On the FDI forward spillover variable, the value of the $t$ ratio is 9,189 . This value is greater than t table at a $1 \%$ significance level. This means that the existence of FDI forward spillover will affect the level of industrial technical efficiency. The existence of a positive coefficient (0.01) indicates the FDI forward spillover will increase the value of technical inefficiency or in other words negatively affect the industrial technical efficiency in East Java.

In line with research by Sari, et al. (2016) which states that the negative effect of FDI forward spillover can occur if goods produced by foreign firms are not widely used by domestic firms as inputs for their raw materials. In this study, the FDI forward spillover harms the technical efficiency. This indicates that the greater production of foreign firms that will be used by the domestic downstream industry will reduce the value of the technical efficiency of the domestic industry. In other words, the domestic downstream industry has become increasingly inefficient to manage its resources by the entry of foreign firms (Markusen and Venables, 1999).

On the market structure $(\mathrm{HHI})$ variable, the value of the $\mathrm{t}$ ratio is 20.076 . This value is greater than t table at a $1 \%$ significance level. This means that the market structure affects the level of industrial technical efficiency. The existence of a positive coefficient $(0.275)$ indicates the greater market structure will increase the value of technical inefficiency or in other words negatively affect the industrial technical efficiency in East Java.

The results above are not following research conducted by Baten, et al. (2010) and Darmawan (2016). In both studies stated that the higher level of market concentration indicates that industrial output is increasingly focused on a particular firm. This can force other firms to make new products that are better and more efficient. This is not in line with large and medium industries in East Java. The higher level of market concentration will reduce the efficiency of the firm so that it becomes less efficient in managing its resources. In other words, if industrial output spreads evenly to many firms it will increase the technical efficiency of these firms.

On the firm size variable, the value of the $t$ ratio is $-36,617$. This value is smaller than $\mathrm{t}$ table at a $1 \%$ significance level. This means that the firm size affects the level of industrial technical efficiency. The existence of a negative coefficient $(-0.523)$ indicates the greater firm size will reduce the value of technical inefficiency or in other words a positive ho on the industrial technical efficiency in East Java.

The discussion above is in line with research conducted by Margono and Sharma (2006). Their research states that companies that have a larger size indicate that the firm can 
optimize the use of its resources. The larger size of a firm, the more efficient it will be to use its existing resources.

\section{Conclusion}

From 2008 to 2014, the average value of the technical efficiency levels on large and medium industries in East Java was best achieved in 2013 which reached 0.957, while the lowest average value occurred in 2010 which only reached 0.904. In terms of industry types, 3 types of industries that had the highest average value of technical efficiency during 2008-2014 were occupied by the Power Plant Machinery Industry, the Locomotive and Carriage Industry, and the Other Electrical and Electronic Cable Industry. In contrast, the Batik Industry, Fish Scavenging Industry and Other Aquatic Biota Salting Industry are the three types of industries with the lowest average technical efficiency.

All factors in this study affect the level of technical efficiency of large and medium industries in East Java. Variable foreign share, FDI horizontal spillover, and firm size have a positive influence on the technical efficiency of the industry. Whereas the variable FDI backward spillover, FDI forward spillover, and the level of market concentration negatively affect the level of technical efficiency of the industry. Based on these results, it's needed to build synergies and sustainable relationships between products produced by domestic and foreign firms. Thus, the presence of foreign firms in East Java could have a positive impact on improving the technical efficiency of the domestic industry both at the upstream and downstream levels.

\section{References}

Aigner, Dennis, C.A. Knox Lovell, dan Peter Schmidt. (1977). Formulation and estimation of stochastic frontier production models. J Econom 6 : 21-37.

Aitken, Brian J. dan Ann E. Harrison. (1999). Do domestic firms benefit from direct foreign investment? Evidence from Venezuela. Am. Econ. Rev. 89 : 606-618.

Badan Koordinasi Penanaman Modal. (2019). Kumpulan Publikasi dan Statistik. Dikutip 15 Juni 2019 dari $h t t p s: / / w w w . b k p m . g o . i d$.

Badan Pusat Statistik. (2017-2018). Kumpulan Berita Resmi Statistik. Dikutip 17 Januari 2019 dari https://jatim.bps.go.id.

Baten, A., Kamil, A. A., \& Haque, M.A. (2010). Productive Efficiency of Tea Industry : A stochastic frontier approach. African Journal of Biotechnology, 9 (25) : 3808-3816.

Battese, George E. dan Timothy J. Coelli. (1992). Frontier production functions, technical efficiency and panel data: with application to paddy farmers in India. J Prod Anal 3: 153-169.

Blalock, G., \& Gertler, P. (2008). Welfare gains from Foreign Direct Investment through technology transfer to local suppliers. Journal of International Economics, 402-421.

Bwalya, Samuel Mulenga (2006). Foreign direct investment and technology spillovers: evidence from panel data analysis of manufacturing firms in Zambia. J. Dev. Econ. 81 : 514-526.

Cheng, Guoqiang. (2012). Opening up of China's agriculture: impact, implication and strategic choice (in Chinese). Chinese Rural Econ. 3 (4-13), 43.

Cheung, Kui Yin dan Ping Lin. (2004). Spillover effects of FDI on innovation in China: evidence from the provincial data. China Econ Rev 15 : 25-44.

Cobb, Charles W. dan Paul H. Douglas. (1928). A Theory of Production. American Economic 
Review 18 (Supplement) : 139-165.

Coase, R.H. (1937). The nature of the firm. Economica 4 : 386-405.

Coelli, Timothy J., D.S. Prasada Rao, Christopher J. O’Donnel, dan George E. Battese. (2005). An Introduction to Efficiency and Productivity Analysis (Second Edition). Queensland: Library of Congress Cataloging in Publication Data, University of Queensland.

Darmawan, Rizal Rahmat. (2016). Pengaruh Perdagangan Vertikal Terhadap Kinerja Industri Alat Angkut di Indonesia [skripsi]. Surabaya (ID) : Universitas Airlangga.

De Backer, K., \& Sleuwaegen, L. (2003). Does Foreign Direct Investment Crowd Out Domestic Entrepreneurship? Review of Industrial Organization, 67-84.

Djankov, S., \& Hoekman, B. (2000). Foreign investment and productivity growth in Czech enterprises. World Bank Econ. Rev, 14, 49-64.

Girma, S., Gong, Y., \& Görg, H. (2009). What Determines Innovation Activity in Chinese Stateowned Enterprises? The Role of Foreign Direct Investment. World Development, 866873.

Görg, H., \& Greenaway, D. (2004). Much Ado about Nothing? Do Domestic Firms Really Benefit from Foreign Direct Investment? World Bank Res. Obser, 19, 171-197.

Jan, K., Vopravil, C. R., \& Office , C. S. (2007). KLE Production Function and Total Factor Productivity. Statistic.

Javorcik, Beata Smarzynska. (2004). Does foreign direct investment increase the productivity of domestic firms? In search of spillovers through backward linkages. Am Econ Rev 943 : 605-627.

Javorcik, Beata Smarzynska. (2008). Can survey evidence shed light on spillovers from foreign direct investment? World Bank Res Obs 23 : 140-159.

Jin, Shaosheng dan Suminori Tokunaga. (2007). Location of Japanese investment in China's food industry. China Rev. 7 : 129-138.

Keller, W. (2009). International Trade, Foreign Direct Investment, and Technology Spillovers, National Bureau of Economic Research. Working Paper.

Khalifah, Noor Aini dan Abdul Talib, B. (2008). Are foreign multinationals more efficient? A stochastic production frontier analysis of Malaysia's automobile industry. International Journal of Management Studies (IJMS), 15, 91-113.

Kohpaiboon, Archanun. (2009). Vertical and horizontal FDI technology spillovers: evidence from Thai manufacturing. ERIA Discussion Paper Serie: No. 2009-08. Jakarta : Economic Research Institute for ASEAN and East Asia (ERIA).

Konings, Jozef. (2001). The effects of foreign direct investment on domestic firms: evidence from firm-level panel data in emerging economies. Econ. Transit. 9 : 619-633.

Kosová, Renata. (2010). Do foreign firms crowd out domestic firms? evidence from the Czech Republic. Rev. Econ. Stat. 92 : 861-881.

Kumbhakar, Subal C. (1990). Porduction frontiers, panel data and timevarying technical inefficiency. J Econom 46 : 201-212.

Lin, Ping, Zhuomin Liu, dan Yifan Zhang. (2009). Do Chinese domestic firms benefit from FDI inflow? Evidence of horizontal and vertical spillovers. China Econ Rev 20 : 677-691.

Lv, L. dan Z. Huang. (2006). Empirical study on the effects of foreign direct investment on Chi- 
nese agricultural products processing industry (in Chinese). Chinese Rural Econ. 5 : $18-24$.

Markusen, James R. dan Anthony J. Venables. (1999). Foreign direct investment as a catalyst for industrial development. Eur Econ Rev 43 : 335-356.

Margono, Heru dan Subhash C. Sharma. (2006). Efficiency and productivity analyses of Indonesian Manufacturing industries. Journal of Asian Economics 17 : 979-995.

Meeusen, Wim dan Julien Van den Broeck. (1977). Efficiency estimation from Cobb-Douglas production functions with composed error. Int Econ Rev 8 : 435-444.

Moulton, B. (1990). An Illustration of a Pitfall in Estimating the Effects of Aggregate Variables on Micro Units. The Review of Economics and Statistics, 334-338.

Neuman, W. Lawrence. (2003). Social Research Methods : Qualitative and Quantitative Approach. Boston : Allyn and Bacon.

Nguyen, C. D., Simpson, G., Saal, D., Nguyen, A.N., \& Pham, N.Q. (2008). FDI horizontal and vertical effects on local firm technical efficiency. Development and Policies Research Center (Depocen), Hanoi, Vietnam.

$\mathrm{Ni}, \mathrm{H}$. (2011). Balance foreign and domestic markets and resources to assure industrial security of agriculture (in Chinese). Chinese Rural Econ. 5 : 57-60, 81.

Nicholson, Walter dan Christopher Snyder. (2012). Microeconomics Theory "Basic Principal and Extensions" Eleventh Edition. South-Western : Cengage Learning.

Organisation For Economic Co-Operation And Develop. (2009). Policy Responses to the Economic Crisis: Investing in Innovation forLong-Term Growth . Retrieved from http:// www.oecd.org/sti/42983414.pdf

Pavelescu, Florin. (2011). Some aspects of the translog production function estimation. Romanian Journal of Economics, vol. 32, issue 1(41) : 131-150.

Rodriguez-Clare, A. (1996). Multinationals, linkages, and economic development. The American Economic Review, 86, 852-873.

Saggi, Kamal. (2002). Trade, foreign direct investment, and international technology transfer: A survey. World Bank Res Obs 17 : 191-235.

Sari, Dyah Wulan, Noor Aini Khalifah, dan Suyanto. (2016). The spillover effects of foreign direct investment on the firms' productivity performances. J Prod Anal 46 : 199-233.

Sharma, Khem R. dan Leung, P.S. (1998). Technical efficiency of carp production in Nepal: An application of the stochastic frontier production function approach. Aquaculture Economics and Management 2 : 129-140.

Soetanto, Tessa Vanina. (2015). Super Slack Based Model Efficiency and Stock Performance of Manufacturing Industry Listed in Indonesian Stock Exchange. Procedia - Social and Behavioral Sciences 211 : 1231-1239.

Sujarweni, V. Wiratna. (2015). Metodologi Penelitian Bisnis \& Ekonomi. Yogyakarta : Pustakabarupress.

Yin, C. (2010). The dual effect of agriculture multinational corporations and internationalization of agriculture (in Chinese). Issues Agric. Econ, 3, 4-10. 